Ms. Martha A. Lyle

Contract Specialist/Administrator

office of Procurement and Contracts Division

Department of Energy

Oak Ridge Operations

P.O. BOX 2001

Oak Ridge, I annessee 37831-8757

\title{
RE: DE-FG05-88ER60728
}

Dear Ms. Lyle:

Report.

Please find the original and two copies of the progress

If you need any additiona? information please contact me at (305) 549-7955.

With best regards and many thanks for your continuous support of our endeavors for the development of new technology and the understanding of cell biology using tracer techniques.

Yours sincerely,

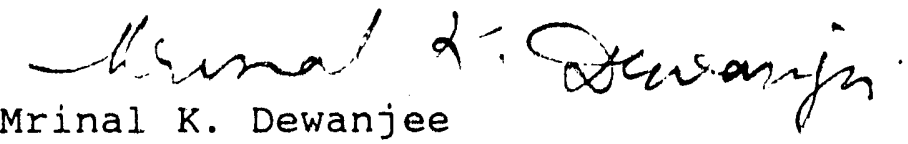

Mrinal K. Dewanjee

Director, Radiopharmaceutical

Laboratory

Professor of Radiology, surgery and

Biomedical Engineering

$\mathrm{MKD} / \mathrm{mf}$. 
PROGRESS REPORT

DOE Grant \# DE-FGO5-88ER60728

LABELING CELLULAR ELEMENTS OF BLOOD WITH TECHNETIUM-99M

for the period september 26, 1988 through August 25, 1990

Principal Investigator: Mrinal K. Dewanjee, Ph.D. Division of Nuclear Medicine

University of Miami, School of Medicine

Miami, FL 33101

\author{
Prepared for the \\ Office of Health and Environinental Research \\ Department of Energy \\ Washington, D.C.
}

August 1990

\title{
DISCLAIMER
}

This report was prepared as an account of work sponsored by an agency of the Unitigd Siates Government. Neither the United States Government nor any agency thereof, nor any of their employees, makes any warranty, express or implied, or assumes any legal liability or responsibility for the accuracy, completeness, or usefulness of any information, apparatus, product, or process disclosed, or represents that its use would not infringe privately owned rights. Reference herein to any specific commercial product, process, or service by trade name, trademark, manufacturer, or otherwise does not necessarily constitute or imply its endorsement, recommendatic, or favoring by the United States Government or any agency thereof. The views and opinions of authors expressed herein do not necessarily state or reflect those of the United States Government or any agency thereof.

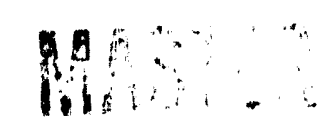


Title: Labeling Cellular Elements of Blood with Technetium $99 \mathrm{~m}$.

\section{SUMMARY}

The purpose of this proposal is to develop new technique of labeling platelets and white cells with Tc-99m radionuclide. The conditions of labeling canine platelets and white cells with the lipid-soluble Tc-99m HMPAO have been optimized. The function of labeled platelets were evaluated by the determination of platelet survival time and recovery and these values were compared with that of In-111 tropolone labeled platelets. These values were found lower than the In-11l labeled platelets. The biodistribution of Tc-99m labeled platelets in dogs indicated that 20-25\% of Tc-99m radioactivity was excreted in urine.

We have discovered that the loss of Tc-99m from labeled platelets is due to the effect of fluid-shear; 20-30\% of Tc-99m labeled small molecules are lost when labeled platelets are injected in vivo; on the other hand this loss is 4-8\% in the resting Tc-99m labeled platelets. We are actively pursuing the role of flow rate, time, shear-stress on this Tc-loss in an in vitro flow-loop. We are also modifying the structure of Tc-99m complex for better TC-99m of anchoring to cycosolic proteins of platelets and white cells.

We developed the bilateral femoral catheterization model for the evaluation of platelet-thrombosis on control and heparin-bonded catheters in dogs. The results were comparable with that of In-11l labeled platelets; a significant decrease of platelet-thrombosis due to heparin-bonding was also observed with Tc-99m labeled platelets.

We are evaluating platelet thrombosis in the hollow-fiber hemodialyzer with $\mathrm{TC}-99 \mathrm{~m}$ and In-l11 labeled platelets; although this artificial kidney was the first artificial organ and most successful in patients of kidney diseases, no quantitative information is available about platelet-consumption and shearinduced platelet-fragmentation during hemodialysis. We have developed the flow-loop for in vitro studies and are using a pig model for quantitation of platelet-consumption during hemodialysis.

We are currently evaluating the new technique of platelet and white cell-labeling with Tc-99m and testing them in animal models of thrombosis and infection (osteo-myelitis). The new complex of stannous-mercaptopyridine-N-oxide (Sn-MPO), we have developed for labeling platelets and white cells is cost-effective, easy to carry out and was found as effective as TC-99m HMPAO.

We are also using the Tc-99m HMPAO labeled mixed white cells in the early diagnosis (3-hour post-injection) of acute and chronic infection in patients and comparing the results with that of In-1.1 oxine labeled white cells. 
The highlights of the achievements are described below:

A. The optimization of labeling conditions

We have successfully carried out the labeling of the platelets and white cells with Tc-99m HMPAO and Sn-MPO.

i). Subcellular distribution of $\mathrm{Tc}-99 \mathrm{~m}$ in labeled platelets and red cells

ii). Development of bilateral femoral catheter-implantation model (dog) for testing of thrombogenicity with Tc-HMPAO labeled platelets

B. Development of a new lipid-soluble stannous-mercaptopyridine $\mathrm{N}-$ oxide complex for cell-labeling with $\mathrm{Tc}-99 \mathrm{~m}$ radionuclide.

Partition coefficient of stannous ion complexes indicate high lipid-solubility and high cellular extraction. This complex is as effective as TC-99m HMPAO. We are modifying the structure of ethylene-cysteine diethyl ester for the formation of a stable Tc$99 \mathrm{~m}$ EC-ester; we are replacing the ethyl group with acetoxymethyl group for intracellular hydrolysis and anchoring of Tc-99m complex to the cytosolic proteins.

i). Optimization of platelet-labeling with Tc-99m pertechnetate with Sn (II) -MPO

C. Development of infection model (soft tissue and bone) for the comparative evaluation of $\mathrm{Tc}-99 \mathrm{~m}$ labeled white cells in the rabbit model. The sensitivity of detection of osteomyelitis decreases in the chronic phase.

D. Effect of rheology on the Tc-99m loss from labeled platelets and white cells

Excessive loss of Tc-99m from labeled cells was a 20-year puzzle, since I first started red-cell labeling at Brigham tospital of Harvard Medical School. The collaboration with the Biomedical Engineering of the University of Miami and the assistance of a graduate student are finally resolving the role of shear-stress on Tc-loss from labeled cells. We are currently using a hollow-fiber dialyzer to induce shear-stress in the in vitro flow-loop.

E. Clinical investigation of Tc-99m labeled white cells

We are using the Tc-99m labeled white cells in patients for the early diagnosis of acute and chronic infection. The larger dose of TC-99m (20 mCi) vs $0.5 \mathrm{mCi}$ for $\mathrm{In}-111$ and easy access of TC$99 \mathrm{~m}$ are two obvious advantages.

F. Development of gamma-emitting oligonucleotide probes for the non-invasing diagnosis of myocardial infarction and evaluation of gene-activation in cancer

In collaboration with the Department of Biochemistry and Molecular Biology, we developed the technique of labeling of antisense oligonucleotide probes with the radionuclides of $I-123$ and In-111 by the conjugation techniques. We are excited about the 
preliminary findings of probe-localization in the myocardial infarct in the rabbit mode?.

G. Modified test development for apyrogenicity testing of Tc-99m labeled radiopharmaceuticals and chelating agents

We had found that the commercial pyrogen-testing kits are not effective, since the chelating agents bind free calcium and invalidate the test by inhibiting the gel-formation in presence of endotoxin. We solved the problem by addition of $60 \mathrm{~mm}$ of calcium ions in the kits.

H. Renovation and relocation of Radiopharmaceutical Research Laboratory in the new Cancer Research Building

The research laboratory had been relocated to the newly-built Papanicolaou Building, close to the laboratory of Molecular Biology. We are well-settled now and our studies are in full gear.

I. Collaboration with regional industries and university for the promotion of non-invasive imaging techniques and development of thromboresistant biomaterials for catheters and dialyzers

We are assisting the cordis Inc. for the testing and development of thromboresistant catheters for the last three years. We startec similar collaboration with CD-Medical Inc. for the testing of their hemodialyzers. We are collaborating in the development and testing of sensitive mercuric-iodide detector with the staif of Biomedical Engineering at Florida International University.

$\mathrm{J}$. Training of undergraduate and Medical college students in the use of tracer techniques and non-invasive imaging

We provided training in the use of radiopharmaceuticals to 4 freshman ( 1 hispanic, 1 black), 3 junior level and 3 medical students. They learnt the techniques of labeling proteins and cells and their applications in the thrombosis and infection models. Their exposure to radiation safety and medical research will stimulate them to participate in career development in medical and graduate studies.

K. DOE Grant Review:

1. Invitation to the DOE Grant Review Panel on SPECT radiopharmaceuticals. April 11-13, 1989. Dulles Airport Hotel (Ramada), Herndon, VA. 1990 .

2. DOE Grant Review of Dr. D. E. Kuhl, Ann Arbor, Michigan,

3. Grant review for the Florida High Tech and Industry Council, Miami, 1990.

L. Other professional and scientific activities

i). Presentation of an invited talk at the International symposium on Platelet Vessel-wall Interaction at Lubeck, W. Germany, June 89,1989 .

Title: Platelet thrombosis on cardiac valve prostheses

ii) Review article on the "Chemistry of Tc-99m labeled Radiopharmaceuticals", for publication in the Seminars of Nuclear Medicine, 1990. 
iii). Publication of review article on "Radioiodination: Theory, Practice and Biomedical Applications". DOE sponsored symposium at Bangalore, 1986.

iv). Title: Radiolabeled platelets in cardiovascular Diseases. July 13, 1989. Albert Einstein College of Medicine. Bronx, N.Y.

v). Presentation of the new cell-labeling technique in the Third International symposium on Technetium in Chemistry and Nuclear Medicine at Padua, Italy, SEpt. 10-15, 1989.

vi). Presentation of the techniques of cell-labeling and applications at the symposium of International society for Radiolabeled Blood Elements at Vienna, Sept. 10-15, 1989.

In brief, our investigations are progressing as planned; new techniques of synthesis of lipid-soluble ligands are being developed. The new findings are being presented and published in scientific Journals and meetings respectively. 
ABSTRACTS :

1. Dewanjee M, Solis E, Mackey S, Kaye M, Palatianos G, Sfakianakis G. Quantification of polymorphonuclear neutrophilic granulocyte (FING) infiltration on Gore-Tex (GT) graft in abdominal aorta of dogs in acute and chronic phase. Proc 15th Ann Mtg of Soc Biomaterials, orlando. April 28- May 2, $1989 \mathrm{p} 139$.

2. Dewanjee MK, Dylowski JR, Robinson RP, Hellman RL, Serafini A. Inhibition of platelet thrombosis on biomaterials by blocking the common pathway of activation of platelets and procoagulant factors with selective calcium ion sequestrants. Proc 15 th Ann Mtg of Soc of Biomaterials, p237, 1989.

3. Dewanjee MK, Rowland S, Robinson R, Halgowich J, Macgregor D, serafini $A$, sfakianakis $G$. The kinetics and quantitation of platelet deposition on control (CPC) and heparin bonded angiocatheter (HBPC) with In-111 labeled platelets in a dog model. ASAIO abstracts. 35th Ann Mtg, Dallas, p 55, May 23-25, 1989.

4. Palatianos G, Dewanjee MK, Robinson R, Novak S, Dewanjee P, Hsu L, Sfakianakis G, Kaiser G. Cuantitaition of platelet loss with In111 labeled platelets in hollow-fiber membranf oxygenator (HFMO) and arterial filter ( $A F)$ during extracorporeal circulation in a pig model. ASAIO abstracts. 35th Ann Mtg, Dallas, p 63, May 23-25, 1989 .

5. Dewanjee MK, Rowland S, Kapadvanjwala M, Georgiou M, Palatianos $G$, MacGregor $D$ and Sfakianakis $G$. The dynamics of platelet-thrombus formation rate (TFR), thrombus retention time (TRT) and rate of embolization (ROE) on control (CPC) and heparin bonded polyurethane angio-catheter (HBPC) with In-111 labeled platelets in a dog model. ASAIO abstracts. 36th Ann Mtg, Washington D.C., p 87, April 24-27, 1990.

6. Dewanjee MK, Palatianos G, Kapadvanjwala M, L Hsu, M Yanis, Ahn $Y$. Increase of intra-platelet free calcium (IPFC) ion during the extracorporeal circulation (ECC) with hollow-fiber oxygenator (HFoarterial filter ( $A F)$ and platelet-thrombosis in a pig model. ASAIO abstracts. 36th Ann Mtg, Washington D.C., p 67, April 24-27, 1990. 7. G. Palatianos, Dewanjee MK, Kapadvanjwala M, Novak S, Kaiser G, Sfakianakis GN. Cardiopulmonary bypass with surface-heparinized extracorporeal perfusion system. ASAIO abstracts. 36th Ann Mtg, Washington D.C., p 66, April 24-27, 1990.

8. Kapadvanjwala M, Dewanjee MK, Sfakianakis GN. Thrombus filter column: a simple device for the quantitation of net thrombus and embolus with In-111 labeled platelets. ASAIO abstracts. 36th Ann Mtg, Washington D.C., p 38, April 24-27, 1990.

9. Dewanjee MK, Rowland $S$, Kapadvanjwala M, Georgiou M, Palatianos $G$, MacGregor D and Sfakianakis $G$. The dynamics of platelet-thrombus formation rate (TFR), thrombus retention time (TRT) and rate of embolization (ROE) on control (CPC) and heparin bonded polyurethane angio-catheter (HBPC) with In-111 labeled platelets (IN-PLI) ir a dog model. SNM abstracts. 37th Ann Mtg, washington D.C., p 891, June 19-22, 1990 .

10. Ganz WI, Smart P, Serafini A, Friden A, Bilsker M, Dewanjee M. Adjunctive role of nuclear medicine for cardiac pathology seen on MR images and echocardiograms. J Nucl Med 31:934, 1990, SNM 
abstracts. 37th Ann Mtg, Washington D.C., p 934, June 19-22, 1990. 11. Dewanjee MK, Kapadvanjwala M, Dewanjee S, Sfakianakis GN. Effect of fluid shear on the loss of Tc-99m from labeled platelets. $\mathrm{J}$ Nucl Med 31:820, 1990, SNM abstracts. 37th Ann Mtg, Washington D.C., p 820, June 19-22, 1990.

12. Dewanjee MK, Ghafouripour AK, Ganz W, MCCarthy K, Serafini A, Sfakianakis GN. Radiodination of proteins by a new conjugation technique activated radiodiodinated paramethoxyisothio-

cyanate. J Nucl Med 31: 907,1990; 37th Ann Mtg, Washington D.C., p 907, June 19-22, 1990.

13. Dewanjee $S$, Dewanjee MK, Kapadvanjwala M, Sfakianakis GN. Fluid shear on the loss of TC-99m from TC-labeled RBCs in a dog model. 8th Int Symp Radiopharm Chem June 24-29, 1990, Princeton, p 24. 14. Dewanjee MK, Ghafouripour AK, Ganz W, McCarthy K, Serafini AN, Sfakianakis GN. Radiodination of proteins by a new conjugation technique activated radiodiodinated paramethoxyisothiocyanate. 8th Int Symp Radiopharm Chem June 24-29, 1990, Princeton, p 336 .

Publications:

1. Dewanjee MK, Mackey ST, Solis E, Kaye MP. Effect of aspirin and low-dose aspirin-persantine treatment on calcification of pericardial tissue valves in calves. Chapter 15, In Calcification and Degeneration of Heart Valve Bioprostheses. Proc Ist Sci Mtg of Cardiac Biological Implants. Eds. Gabbay $S$ and Cabrol $C$. Ameur Communication Medicale. pp 191-204, 1989.

2. Dewanjee MK. Platelet thrombosis in cardiac valve prosthesis.

3. Dewanjee MK. Radioiodination: Theory, Practice and Biomedical Applications. DOE sponsored Symposium in Bangalore, India, 1986. Indian $J$ Nucl Med 4(3):162-174, 1989.

4. Plevak DJ, Halma GA, Forstrom LA, Dewanjee MK, O'connor MK, Moore SB, Krom RAF, Rettke SR. Thrombocytopenia after liver transplantation. Trans Proc 20(Suppl 1): 630-633, 1988.

5. Dewanjee MK, Chowdhury SC, Herold $T$, Serafini AN, Sfakianakis GN. Endotoxin testing with Limulus amoebocyte lysate in a radiopharmaceutical containing chelated metallic radionuclides ard chelated agents. J Nucl Med 31(2): 243-245, 1990.

6. Dewanjee MK. Radiclabeled platelets in cardiovascular diseases. In "Clinical Applications of Radiolabeled Platelets." Eds. Kessler Ch., Hardeman MR, Henningsen H, Petrtovici JN. Kluwer Academic Publishers. Boston 1990, pp 61-110

\section{PLNRICATIONS (IN PRESS}

1. Dewanajee MK, Robinson RP, Hellman RL, Serafini A. Technetiumlabeled platelets: comparison of labeling with a new lipid-soluble $\mathrm{Sn}$ (II)-mercaptopyridine $\mathrm{N}$-oxide and TC-99m-HMPAO. Int $\mathrm{J}$ Nucl Med Biol, 1990

2. Dewanjee MK. Radiolabeled platelets in the monitoring of drugefficacy in animal molels. Thrombotic and Haemorrhagic Disorders. Vol 2, 1990. Springer-verlag, vien.

3. Dewanjee MK, Ghafouripour AK, werner RK, Serafini AN, Sfakianakis GN. Development of sensitive radioiodinated anti-sense 
oligonucleotide probes by conjugation technique. Bioconjugate Chemistry, 1990.

4. Dewanjee MK, Palatianos G, Kapadvanjwala M, Hsu L-C, Yanis M, Ahn $Y$. Increase of intra-platelet free calcium (IPFC) ion during the extracorporeal circulation (ECC) with hollow-fiber oxygenator (HFO-arterial filter (AF) and platelet-thrombosis in a pig model. Trans ASAIO 36, 1990.

5. Dewanjee MK, Rowland S, Kapadvanjwala M, Georgiou M, Palatianos G, MacGregor D and Sfakianakis G. The dynamics of platelet-thrombus formation rate (TFR), thrombus retention time (TRT) and rate of embolization (ROE) on control (CPC) and heparin bonded polyurethane angio-catheter (HBPC) with In-11l labeled platelets (IN-PLT) in a dog model. Trans ASAIO 36, 1990.

6. G. Palatianos, Dewanje€ MK, Kapadvanjwala M, Novak S, Kaiser G, Sfakianakis GN. Cardiopulmonary bypass with surface-heparinized extracorporeal perfusion system. Trans ASAIO 36, 1990.

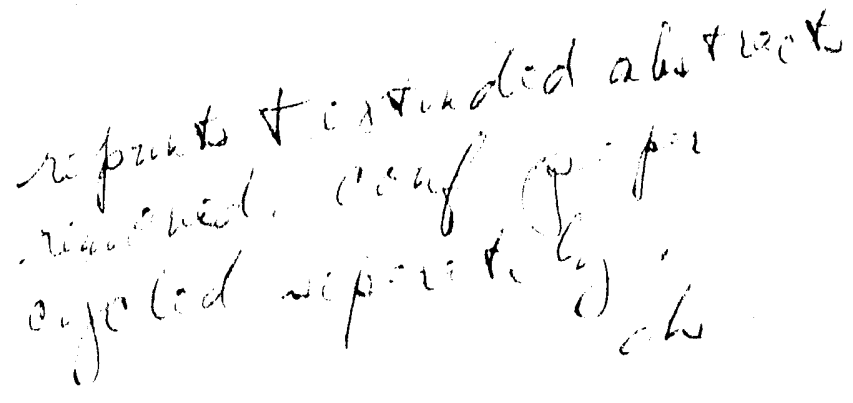



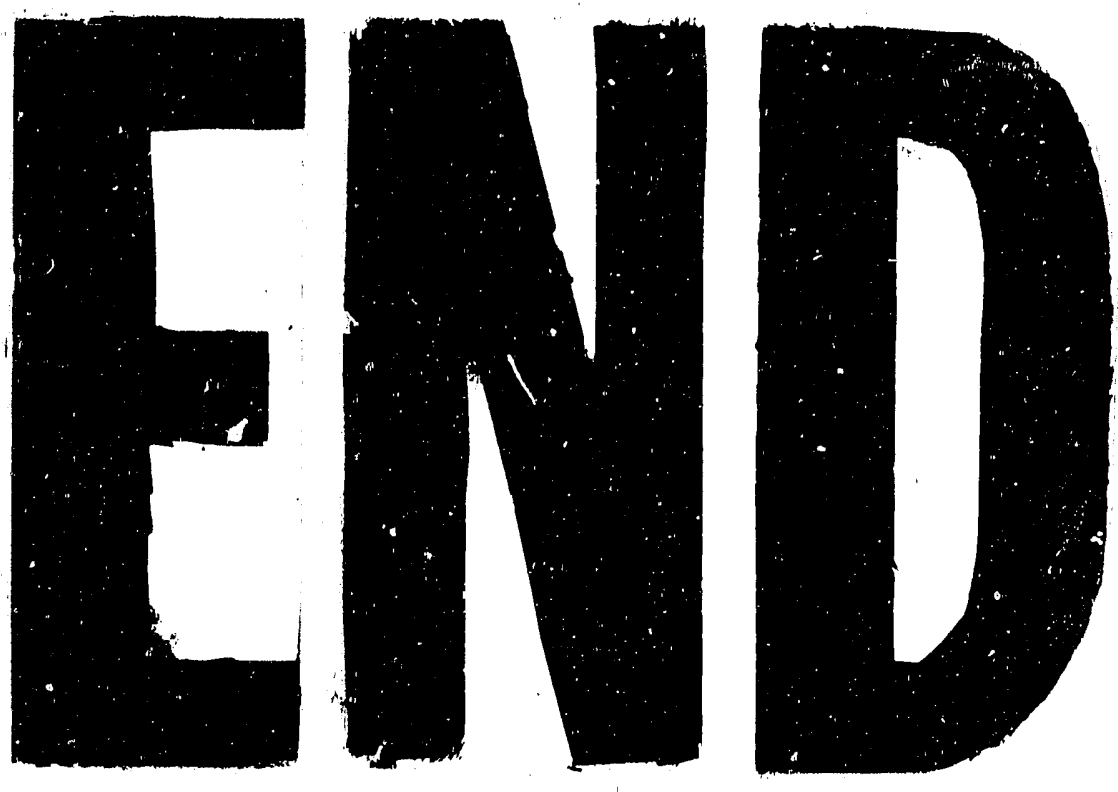

4
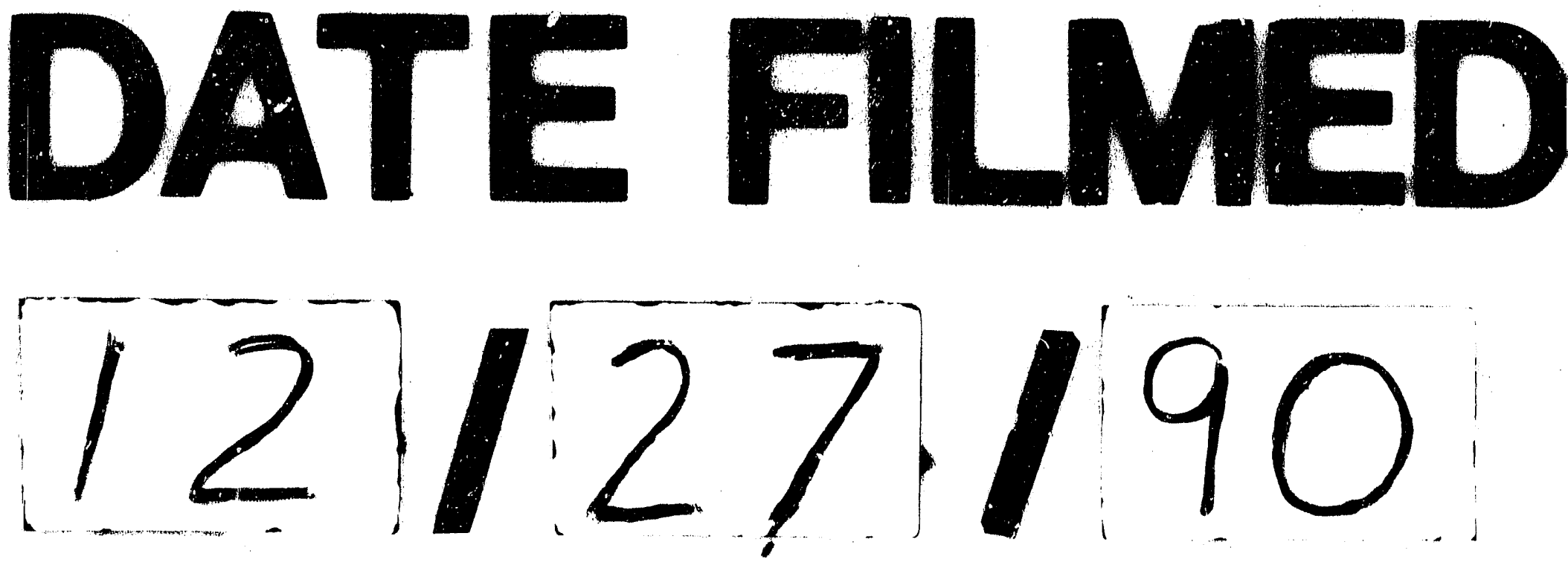
